\title{
Chapter 8 Article 231 of the Versailles Treaty and Reparations: The Reparation Commission as a Place for Dispute Settlement?
}

\author{
Jean-Louis Halpérin"
}

It is more inspiring to speak about a success story in international law than about a failure. It is more exciting to study a completely new subject in legal history than to try to elbow one's way into a rich literature about a well-known matter. The issues of Article 231 of the Versailles Treaty and of Reparations present concurrently the two less desired positions.

It is widely known that the process of reparations was abandoned after ten years of successive attempts to adapt it to the economic and political context of the period between 1921 and 1931, leading from the end of World War I to the Great Depression. Concerning Germany, the reparations process gave rise to the payment of less than twenty-two billion gold marks, which amounts to one sixth of the foreseen sum of the 1921 Bill and Schedule of Payments. ${ }^{1}$ While the Allied powers, especially the successive governments of France, were dramatically disappointed by this low score, the German people were upset by Article 231 and the debt linked with this reparations process, one of the main elements of Nazi propaganda.

Furthermore, this fiasco has been broadly analyzed by jurists and economists of the interwar period, as well as by historians. Concerning France, it is noteworthy that several doctoral theses in law (at a time when economics was taught inside the Law Faculties) were devoted to reparations issues, even if they are not so interesting from the perspective of international law. ${ }^{2}$ The contrast is strong between this relatively poor litera-

* Professor of Legal History at the Ecole Normale Supérieure PSL, Chairman of the Centre of Legal Theory and Analysis (UMR 7074).

1 Richard Castillon, Les Réparations allemandes: Deux expériences, 1919-1932, 19451952 (PUF 1953) 65-66.

2 André Garrigou-Lagrange, Le Problème des réparations. La technique des règlements (doctoral thesis Paris 1923); Pierre Noël, L'Allemagne et les réparations (doctoral thesis Paris 1924); Louis Imbert, Le Règlement des réparations (doctoral thesis Aix-Marseille 1935). 
ture and the 1938 doctoral thesis in history written by Étienne Weill-Raynal, which contains many developments and analyses of great interest. ${ }^{3}$

What is worth saying today about reparations in a symposium about the history of international law with a focus on dispute settlement? I have chosen the Reparation Commission as a focal point, although I do not claim to make and to present an exhaustive examination of it. On one hand, many things have been written by Étienne Weill-Raynal, who himself worked in the French Delegation of the Reparation Commission. On the other hand, the records of the Reparation Commission, kept in the French National Archives, are collected in more than four thousand boxes, of which I have not been able to consult all. ${ }^{4}$ Having made spot checks in these Archives for the period between 1920 and 1924, I would like to analyze the working process of the Reparation Commission until the implementation of the Young Plan, which was a kind of divestiture for the Commission. As a very original kind of international organization, the Reparation Commission was a hybrid institution based on the cooperation of national delegations of the Allied powers that tried to dialog with the German diplomats. With an ambivalent status, it was a political and administrative authority with some competences that could be compared to those of a tribunal. Before studying the attempts to make the Reparation Commission a place for dispute settlement of the reparations issue, it is necessary to begin with Article 231 of the Versailles Treaty as an important milestone to settle the double-pronged dispute about reparations: the dispute between Allied powers and Germany and the dispute among the Allied nations.

\section{Three Steps Towards Drafting Article 231 of the Versailles Treaty and One Step Towards the Reparation Commission}

The process leading to the establishment of the Reparation Commission has to been understood as a sequence of three steps in the writing of Article 231 of the Versailles Treaty and one step to establish a commission to settle the amount of reparations.

3 Étienne Weill-Raynal, Les Réparations allemandes et la France (Nouvelles Éditions Latines 1938, 3 vol).

4 French National Archives, AJ/6/76 to AJ/6/4342. The study focuses on the minutes of the Reparations Commission meetings from 1920 to 1924. On the issues about the Dawes and Young plans, see d'Argent (ch 9). 


\subsection{An American Idea}

On January 1918, President Wilson issued a statement known as the Fourteen Points, saying in point seven that Belgium had to be 'restored.' For the American President, this meant that compensation would be paid by Germany to Belgium because of the violation of its neutrality. Behind this statement was the idea that the German war against Belgium was a severe breach of international law, whereas the war against the other Allied powers was not a radically unjust or illicit one. At the beginning of November, 1918 the German Government and the Allied Powers accepted to discuss an Armistice on the basis of the Fourteen Points. In a note, written by the United States Secretary of State Robert Lansing and accepted by the Allies, it was specified that the Armistice would imply the reparations of all damages caused to civilians by the German aggression. ${ }^{5}$ This note, enlarging the field of reparations (henceforth extended to other countries than Belgium), was transmitted to Germany and accepted on 4 November 1918.

\subsection{A British Enlargement}

During the Peace Conference, the British proposed first to include the war costs in the reparations (at the beginning the British claims were harsher than the French ones), but then had to take account of the American opposition towards a war indemnity, like the one in the 1871 Frankfurt Peace Treaty. ${ }^{6}$ Nevertheless, it was decided to include into reparations the pensions paid to war widows and disabled veterans, which was not exactly in line with the principle of compensating (only) civilians as laid out in the Armistice talks. At the same time, two Commissions-one on the Responsibility of the Authors of the War and on Enforcement of Penalties, the other of Reparation for Damages - were established. Whereas the first (with the Dean of the Paris Law Faculty, Larnaude, among its members) failed to create an international Tribunal on war crimes, the second (with Klotz and Loucheur as French delegates) laid the foundations of the reparations process.

5 Weill-Raynal (n 3) vol 1, 25.

6 Marc Trachtenberg, 'Reparations at the Peace Paris Conference' (1979) 51 The Journal of Modern History 24. 


\subsection{An Inter-Allied Compromise}

The American Delegation proposed to separate the issues of sanctions and of reparations and prepared the draft for articles 231-243, which were to be included into Part VIII of the Versailles Treaty devoted to 'Reparation.' The most famous of these provisions, article 231, went as follows:

The Allied and Associated Governments affirm and Germany accepts the responsibility of Germany and her allies for causing all the loss and damage to which the Allied and Associated Governments and their nationals have been subjected as a consequence of the war imposed upon them by the aggression of Germany and her allies.

The article implies that it is not the matter of a penal responsibility for a war of aggression, but of a civil liability; ie, Germany must restore the status quo ante for civilians of the Allied Powers that have suffered damages (which was not the case for the American people). The German liability, as a source of reparations, was conceived according to the rules of the Napoleonic Code and of the more recent German Civil Code (BGB), both of which were quoted by the French delegation. ${ }^{8}$ The Reparations system was considered as an expression of social solidarity towards the civilian victims of the war and, as a German writer called it in a 1928 dissertation, of 'neo-collectivism' or the socialization of risks. ${ }^{9}$ It was also in the spirit of French statutory laws voted for before the Versailles Treaty that concerned war pensions and devastated regions (laws of 31 March and 17 April 1919).

Article 231 must neither be read in isolation nor in the erroneous German translation, which transformed Germany into the 'author of the war, entailing the idea of criminal guilt. On the contrary, Allied Governments recognized in Article 232 that the resources of Germany were not adequate, and they limited the reparations to 'compensation for all damage done to the civilian population, while separating the special case of Belgium with the reimbursement by Germany of the sums borrowed by Belgium during the war. Furthermore, Article 235 provided a sum of 20 billion gold marks to be paid before the 31 March 1921.

7 The English version of the Versailles Treaty uses the singular, whereas the French version uses the plural Reparations. It is the same for the Reparation Commission, in French the Commission des Réparations.

8 Camille Bloch and Pierre Renouvin, 'L'article 231 du Traité de Versailles. Sa genèse et sa signification' (1932) 10 Revue d'histoire de la Guerre mondiale 1.

9 Wolfgang Bonde, Das Problem der Reparation (Jena dissertation 1928) 23. 


\subsection{The Reparation Commission as a New Deal}

As accepted by the German Government and Parliament (through the ratification of the Versailles Treaty), Articles 231 and 232 appeared as a preliminary judgment to resolve the dispute settlement about reparations. The question of fixing the amount of reparations was delegated to the Reparation Commission, as the Allied Governments were not able to find an agreement about an achieved process of evaluation or a lump sum. As a second deal based on American proposals in April and May 1919, it was decided in Article 233 to create an 'Inter-Allied Commission' in order to settle this part of the dispute. The Treaty insisted that the German Government recognize the power and authority of the Reparation Commission (Art 240): the Germans had to provide for the salaries and expenses of the Reparation Commission, to supply all necessary information to the Commission and to accord to its members the same rights and immunities as diplomatic agents. As a counterpart, the Reparation Commission had 'to give to the German Government a just opportunity to be heard' and to consider from time to time 'the resources and capacity of Germany. The Reparation Commission was empowered to determine before 1 May 1921 the amount of the damage for which compensation was to be made by Germany (Art 233), to draw up a schedule of payments, then to modify it according to the evolution of German resources. The power to cancel any part of the reparations debt was reserved to the Allied Governments. The compromise gave birth to an ambiguous institution that could claim to be an international authority, if not a tribunal.

\section{The Failure to Affirm the Reparation Commission as an Independent Tribunal}

From 1920 to 1923, the Reparation Commission worked hard and tried to affirm its competences as a kind of tribunal. But the gap between this idea of an independent judiciary and reality appeared quickly, with this model of dispute settlement being strongly challenged as early as December 1922.

\subsection{The Ambiguous Status of the Reparation Commission}

The fact that Part VIII of the Versailles Treaty was prepared inside the Peace Conference by the Commission of Reparation for Damages (with a special 
Organization Commission of the Reparation Commission presided by Loucheur and with future members of the Reparation Commission like Bradbury, Bertolini and Theunis) explains why many features of the Reparation Commission were determined by Part VIII and its Annex I and II (which could be amended by the state members of the Commission, unlike the Treaty itself). ${ }^{10}$ Whereas Annex I gave the list of damages to be compensated by reparations, Annex II fixed the main characteristics of the Reparation Commission in 23 paragraphs. The Commission was composed of one Delegate and one Assistant Delegate (present in the meetings, but without the right to vote, except when taking place of the Delegate in case of illness or necessary absence) for each of the four great Allied Powers (United States, Great Britain, France and Italy) and in addition one Delegate of a fifth nation, alternatively Belgium, Japan (only for damages at sea) and the Serb-Croat-Slovene State (for reparations paid by Austria, Hungary or Bulgaria).

The principal permanent Bureau of the Reparations Commission was placed in Paris. Under the authority of a Chairman and a Vice-Chairman, elected by the Delegates, the Commission was authorized to appoint officers, agents and employees. All proceedings of the Commission were required to be private, except for special reasons decided by the Reparations Commission. It was also repeated that the Commission had to hear the German Government (if this Government so desired). More original were the clauses of paragraphs 11,12 and 13 of Annex II. The first one said that the Commission should 'not be bound by any particular code or rules of law or by any particular rule of evidence or of procedure', but should be 'guided by justice, equity and good faith' through the creation of 'rules relating to methods of proof of claims'. The price of this autonomy and of the power to interpret the provisions of the Treaty about 'the whole reparation problem' $(\mathbb{1 2})$ was the required unanimity for questions involving the sovereignty of any of the Allied Powers, for any postponement of the payment of instalments falling due between 1921 and 1926 and questions of the interpretation of the provisions of Part VIII of the Treaty ( $\$ 13)$. In case of default by Germany in the performance of any obligation concerning the reparations, the Reparation Commission could only provide recommendations to the Allied Powers $(\mathbb{1 7})$. It was determined that the Reparation Commission would be dissolved after payment of all the

10 The German text of Annexes I and II can be read in Calmette (ed), Recueil de documents sur l'histoire de la question des réparations (Alfred Coste 1924) 131. 
amounts paid to Germany. Unlike a Tribunal, the Reparation Commission was not linked by law and was not able to decide self-executing rulings.

The nature of the Reparation Commission remained largely undetermined when its first meeting took place in Paris, on 24 January 1920 (after a British-French conference in December 1919 decided that the chairman of the Reparation Commission would be the French delegate). Among the Delegates, the British John Bradbury (former Head of the Treasury and acquaintance of Keynes), the Belgian Georges Theunis (who was originally trained as an engineer, but dealt with economic questions after World War I) and the American Albert Rathbone (Assistant Secretary of the Treasury) were specialized in financial issues, whereas the other delegates were administrators or judges (the French Jonnart, ex-governor of Algeria and senator re-elected in January 1920, the Italian Bertolini, ex-minister, and the judge D'Amelio, future president of the Court of cassation under the fascist regime). ${ }^{11}$ After electing Jonnart as chairman, the members of the Reparation Commission agreed quickly about their work methods: meetings of the Delegates (generally with the presence of Assistant Delegates) at least two times each week, adoption of standing orders, choice of a British Secretary General (Salter, then after July 1922 McFadyean, who was formerly the secretary general of the British Delegation), and the organization of different services (Financial, Restitutions, Legal). ${ }^{12}$ The Reparation Commission, was confronted with the two refusals of the American Senate (in November 1919 and in March 1920) to ratify the Versailles Treaty. It was decided to maintain the two American Delegates as Observers (with a period of suspended participation between February and May 1921 until the decision of the new United States President to keep the Delegation): these American Delegates (Roland Boyden, who was trained as a lawyer, and Colonel Logan), while unofficially attending the meetings of the Reparation Commission without the right to vote, were very active in proposing solutions of compromise in the discussions.

As said in the standing orders of the Reparation Commission, the Commission comprised a national organization, with delegates defending their national interests, and an international organization. ${ }^{13}$ There is no doubt that the Delegates, accompanied by civil servants of their country (directed

11 Andrew Williams, 'Sir John Bradbury and the Reparation Commission 19201925' (2002) 13 Diplomacy and Statecraft 81.

12 AJ/6/76; Commission des Réparations, Rapport sur les travaux de la Commission des Réparations de 1920 à 1922 (Félix Alcan 1923, 2 vol), notably the introduction by Andrew McFadyean, 1-132.

$13 \mathrm{AJ} / 6 / 76,80$. 
by a Secretary General, Aron for France), represented their respective Governments. If they did not agree with the instructions of their governments, they had logically to resign. The French Delegation was particularly unstable: after one month, Jonnart resigned for health reasons and was replaced by Poincaré, whose mandate as President of the French Republic had come to end in February 1920. The presence of Poincaré should have increased the influence of the Commission, but Poincaré resigned in May 1920 after the San Remo Conference, considering that the Reparation Commission would 'be inevitably deprived of the most important part of its powers.' ${ }^{14}$ The new French Delegate and chairman, Louis Dubois (a politician and exminister) had less prestige than Poincaré (whom he consulted as French Prime Minister in 1922-1923) ${ }^{15}$ and was replaced in September 1922 by Louis Barthou, the most active French President of the Reparation Commission from 1922 to 1926. Finally, the last French President was Fernand Chapsal (senator and ex-minister). Poincaré, Barthou and Chapsal conjoined the Presidency of the Commission with their mandate in the French Senate, which was not in favour of the political independence of the Reparation Commission. Poincaré recognized in April 1920 that 'the Delegates represented their respective government' and could not agree with too great sacrifices for their country. ${ }^{16}$ Despite a feeling of Inter-allied constitutional distrust, the votes inside the Commission were in general unanimous, with the French President used his casting vote only three times. ${ }^{17} \mathrm{It}$ is noteworthy that his casting vote was not used for the 26 December 1922 ruling about the German default in wood deliveries, the French and Belgian justification for the Ruhr occupation, because of the Belgian and Italian votes. ${ }^{18}$

\subsection{The Obstacles for Transforming the Reparation Commission into an Independent Tribunal}

While the idea of a French preponderance has to be nuanced, the possibility for the Reparation Commission to act as a true international organization was limited. The Legal Service of the Commission, in which the most famous member was Massimo Pilotti (the future first President of the

14 AJ/6/77 (19 May 1920).

15 Weill-Raynal (n 3 vol 2, 234-235.

16 AJ/6/77 (26 April 1920) 14.

17 Weill-Raynal (n 3) vol 1, 153.

$18 \mathrm{AJ} / 6 / 80$ (26 December 1922) 21. 
European Court of Justice at Luxemburg), and which was endowed to prepare the leasing contract of the Hotel Astoria in Paris, talked about a 'legal personality in the view of international law' for the Reparation Commission. ${ }^{19}$ The Legal Service argued that the Reparation Commission was more powerful than the 1856 Danube European Commission or the preexisting International Offices. If this argumentation justified the capacity of contracting and of transferring payments to the Commission, as per the diplomatic privileges of its members, it remained an 'uncertainty as regarded its civil personality' according to Poincaré. ${ }^{20}$ When the Commission decided to open a secondary office in Berlin, it was very difficult to 'dilute the principle of national' representation of each Delegation and to develop the idea of independent international agents (especially with respect to chief economists) for the members of the services. ${ }^{21}$ Keeping the deliberations secret (the minutes of the Reparation Commission were labelled confidential, but there were problems with leakages of information, as is said in a meeting on 20 May 1921) did not contribute to establish the Commission as an autonomous organ, whereas the reading of these minutes bear witness of serious efforts of friendly cooperation between the Delegates. ${ }^{22}$

One can also speak of a gap between discourse and reality regarding the nature of the powers of the Reparation Commission. It was repeated that the Commission had to be 'impartial and just, ${ }^{23}$ as a kind of sovereign tribunal (a court of appeal or a court of cassation in the French version) ${ }^{24}$ judging the claims of the Allied powers and taking account (in some hearings) of the arguments of the German Kriegslastenkommission. ${ }^{25}$ But it cannot be seriously said that the Reparation Commission made impartial rulings among equal litigants. The Delegates were both judges and parties (or advocates, as wrote Weill-Raynal) ${ }^{26}$, distrusting the fantastic (because very low) figures presented by the German Government about the Reparations and establishing the non-performance of coal deliveries (very soon in June 1920, then in December 1922). ${ }^{27}$

$19 \mathrm{AJ} / 6 / 76,149$.

20 AJ/6/77 (26 April 1920).

21 AJ/6/77 (5 May 1920).

22 Aj/6/78 (20 May 1921).

23 AJ/7/77, Speech by Jonnart (24 January 1920).

24 AJ/6/77, Speech by Theunis (17 May 1920); McFadyean (n 12) 7.

$25 \mathrm{AJ} / 6 / 79$ (30 August 1922).

26 Weill-Raynal (n 3) vol 1, 157.

27 AJ/6/77 (23 June 1920); AJ/6/80 (26 December 1922). 
The Commission had to decide issues of interpretation of the Versailles Treaty and was not obliged to follow the opinions (that could be mixed between a majority and a minority of dissenting opinions) of its legal service. ${ }^{28}$ It had to determine its relationship with other bodies, including arbitration tribunals (about the issue of tank steamers claimed by the United States in April 1920), which made clear that the Commission itself was not an arbitration tribunal. ${ }^{29}$ The Commission took on the important work of checking the calculations of the claims presented by each country about its own active reparations debt. The 1921 payment statements were established sixteen months after serious reports, for example, from Bradbury about the French claims. ${ }^{30}$ But the Reparation Commission did not create explicit rules relating to methods of proving these national claims. All of this substantial amount of work, which was kept in the Archives of the Commission, was in the end useless for establishing the amount of payments.

\subsection{The Turning Point of 1922}

The Commission was quickly by-passed in 1920 and 1921 by a succession of governmental conferences that set out to reconsider the agenda of German payments. ${ }^{31}$ The establishment of the 1921 Schedule of Payments was the outcome of a bargain (the official meeting lasted only 45 minutes) between the national Delegates rather than the result of deep deliberation inside the Reparation Commission. ${ }^{32}$ The Reparation Commission was then short-circuited by the French-German agreement about reparations in kind, decided in Wiesbaden in October 1921 and needing derogations to part VIII and its Annexes of Versailles Treaty. ${ }^{33}$ In March 1922, the Reparation Commission unanimously imposed severe conditions in exchange for the allowance of a delay for Germany. ${ }^{34}$ But, a few months later with the 'sensational fall' of the mark and the German request for a new moratori-

$28 \mathrm{AJ} / 6 / 76,128-131$.

29 AJ/6/77 (26 April 1920).

30 AJ/6/78 (20 April 1921).

31 Bruce Kent, The Spoils of War: The Politics, Economics and Diplomacy of Reparations 1918-1932 (Clarendon Press 1989) 92.

32 AF/6/78 (27 April 1921); Pierre d'Argent, Les Réparations de guerre en droit international public (LGDJ and Bruylant 2002) 87-88.

33 Weill-Raynal (n 3) vol 2, 150-156.

34 AJ/6/79 (21 March 1922). 
um, the Reparation Commission was clearly divided: Bradbury proposed (in August, and in a more developed way in October 1922) a complete plan for rescheduling the German debt and initiating foreign loans to Germany, but was rejected by a vote on 31 August 1922 (two votes against from France and Belgium, one abstention from Italy) and replaced by an Italian-Belgian proposal (supported by France) enjoining the German Government to make a deep financial and monetary reform. ${ }^{35}$ In December 1922, the Commission was unanimous in taking note of the non-execution of timber (then coal) deliveries, but the British Delegate did not vote for the declaration qualifying this non-execution as a 'default' (the United States Delegate acted as an amicus curiae to attenuate the German default). ${ }^{36}$ Bradbury accused Barthou of acting 'behind [the] back' of the Commission, with the support of some bureaucrats, but only in favour of the French Government. Bradbury said that 'the Commission had to judge as fairly as it could, having regard to its composition, the way in which to acknowledge the inconsistence between this composition and a judicial status. When Barthou suggested that the Commission must not live in an 'atmosphere of politics' ('politics must remain outside the scope' was also one of his sentences) but that 'its role was essentially judiciary' he was contradicted by the different appreciations of the consequences of the German default, the source of the division among Allied Powers about the Ruhr Occupation. ${ }^{37}$ The end of the Ruhr crisis, decided in a London Conference with the participation of the Reparation Commission, was a divestiture of the Commission in favour of a pool of bankers and conducted by the Americans Dawes and Young. ${ }^{38}$ The Commission was then reorganized, with fewer meetings in Paris and only attended by Associate Delegates, before being disbanded in $1930 .{ }^{39}$ The idea of such a body, internationally representative in scope, although not judicial in practice, had definitely sunk following the reparations process, but it can be said that the debates of December 1922 showed the true deadlock of the Reparation Commission. It was impossible for the Commission to decide like a Tribunal with members consisting of representatives of their Government who were deprived of any guarantee or spirit of independence. In the final analysis, Delegates are not Judges.

$35 \mathrm{AJ} / 6 / 79$ (31 August 1922).

$36 \mathrm{AJ} / 6 / 80$ (26 December 1922) 20.

37 AJ/6/80 (26 December 1922), 13.

38 Weill-Raynal (n 3) vol 2, 500-522.

39 ibid vol 3, 206; Leonard Gomes, German Reparations 1919-1932 (Palgrave Macmillan 2010) 177. 
